\title{
Image-Based Sexual Abuse: A Comparative Analysis of Criminal Law Approaches in Scotland and Malawi
}

\author{
Seonaid Stevenson-McCabe and Sarai Chisala-Tempelhoff
}

\begin{abstract}
Technology-facilitated violence and abuse including image-based sexual abuse (IBSA) is a phenomenon affecting women and girls around the world. Abusers misuse technology to attack victims and threaten their safety, privacy, and dignity. This abuse is gendered and a form of domestic and sexual violence. In this article, the authors compare criminal law approaches to tackling IBSA in Scotland and Malawi. We critically analyze the legislative landscape in both countries, with a view to assessing the potential for victims to seek and obtain redress for IBSA. We assess the role criminal law has to play in each jurisdiction while acknowledging the limits of criminal law alone in terms of providing redress.
\end{abstract}

Keywords: Image-based sexual abuse; law; Scotland; Malawi; feminism; domestic and sexual violence

\section{Introduction ${ }^{1}$}

The criminal law is often perceived as a crucial tool in combating technologyfacilitated violence and abuse (TFVA). In recent years, there has been an increased focus on criminalizing TFVA, with numerous jurisdictions attempting to regulate the digital domain. ${ }^{2}$ In this research, we discuss the criminal legislative landscapes in Scotland and Malawi relating to one particular form of TFVA: image-based sexual abuse (IBSA).

The Emerald International Handbook of Technology-Facilitated Violence and Abuse, 513-532

Copyright (C) 2021 Seonaid Stevenson-McCabe and Sarai Chisala-Tempelhoff

Published by Emerald Publishing Limited. This chapter is published under the Creative

Commons Attribution (CC BY 4.0) licence. Anyone may reproduce, distribute, translate and create derivative works of these chapters (for both commercial and non-commercial purposes), subject to full attribution to the original publication and authors. The full terms of this licence may be seen at http://creativecommons.org/licences/by/4.0/legalcode.

doi:10.1108/978-1-83982-848-520211038 


\section{Seonaid Stevenson-McCabe and Sarai Chisala-Tempelhoff}

While often colloquially referred to as "revenge porn," the literature in this area has provided detailed explanations as to why the term is inappropriate (see, e.g., Gosse, this volume; McGlynn \& Rackley, 2016). The terminology adopted in this research is that of IBSA, as developed by McGlynn and Rackley, to mean the "non-consensual creation and/or distribution of private sexual images" (see, e.g., McGlynn \& Rackley, 2016, Image-based sexual abuse section, para 1; McGlynn \& Rackley, 2017, p. 536).

IBSA operates as a broad term which captures a range of connected practices and which emphasizes the abusive nature of these behaviors (McGlynn \& Rackley, 2016). As noted by McGlynn and Rackley (2016, Image-based sexual abuse section, para 1):

The non-consensual creation and/or distribution of private, sexual images is a serious harm often resulting in considerable mental and physical injuries. It is a form of harassment and often part of a pattern of coercive, domestic abuse. It is also a breach of the fundamental rights to privacy, dignity, and sexual autonomy, with women (and victims are mostly women) being forced offline and blamed or targeted for expressing themselves sexually through imagery.

This analysis of IBSA accurately captures some of the experiences of women and girls in Scotland and Malawi. In Scotland, the long-term impact on women and girls, including anxiety, self-harm, and suicide has been recognized by Scottish Women's Aid (BBC News, 2017, para 19), and it is understood that this behavior often forms part of a wider pattern of abuse (Scottish Parliament, 2015, para 24). In the Malawian context, victims have not only been forced offline but have fled the country as a result of the shame associated with IBSA (Chisala-Tempelhoff \& Kirya, 2016, p. 3). Equally, we find McGlynn, Rackley, and Houghton's (2017; McGlynn \& Rackley, 2016, Image-based sexual abuse section, para 2) approach to locating IBSA as part of the "continuum of sexual violence" useful. Recognising that IBSA shares characteristics with other sexual offenses can help to ensure that appropriate legal safeguards and support networks are made available to victims everywhere (McGlynn \& Rackley, 2016, para 2), including in Scotland and Malawi.

In 2018, the Scottish and Malawian Governments entered into The Global Goals Partnership Agreement which encourages collaboration between their respective Governments (The Republic of Malawi and Scotland, 2018). With reference to gender equality, the Agreement notes that the Parties intend to work together "to formulate, enforce and implement laws and policies related to gender-based violence" (Republic of Malawi and Scotland, 2018, Annex, Global Goal 5, para 6). We have been working collaboratively in recent years to discuss the challenges IBSA presents for women and girls and those working to support them in our respective nations. While we acknowledge that IBSA can impact on people of any gender, those most likely to be victims in Scotland and Malawi are women and girls (see, e.g., Chisala-Tempelhoff \& Kirya, 2016, p. 2; Scottish Parliament Justice Committee, 2016, para 44). It is therefore hoped that this research advances the 
discussion on seeking redress for IBSA, while supporting the shared Governmental objective to collaborate in the implementation of laws and policies related to genderbased violence.

Both Scotland and Malawi have criminal legislation which can be used to tackle IBSA. ${ }^{3}$ Yet neither legal system is providing a comprehensive solution. In this chapter, we highlight the potential for the criminal law in each country to provide redress, while acknowledging the importance of wider civic campaigning and education. We begin by addressing the potential for criminal prosecution in Malawi and then turn to assess the successes and shortcomings of Scotland's approach to IBSA. In conclusion, we highlight the inherent shortcomings of existing criminal law responses and the risks of attempting to "transplant" the legislative approach from one jurisdiction into another without examining important contextual differences. Finally, we emphasize the importance of public education and multi-sector collaboration as part of a multi-pronged strategy for responding to IBSA.

\section{Malawi: Potential for Prosecution}

Malawi has several legislative provisions which could be used to protect victims of IBSA. The Constitution of the Republic of Malawi (1994) protects rights at the core of tackling IBSA, including rights to privacy, equality, dignity, and the rights of women (Chisala, 2019b, para 3). Since the entry into force of the Constitution in 1994, legislation has progressively been introduced to enhance gender equality, promote the rights of women, and allow for the prosecution of gender-based violence, including IBSA. However, to fully understand the legislative context in which IBSA could be tackled using this recent, progressive legislation, it is also crucial to understand the ways in which criminal law provisions are currently being used to silence, control and shame women and girls. In some ways, the very body of laws put in place to purportedly protect women has been used to prosecute women in deeply gendered ways.

One such provision is section 137 of the Malawi Penal Code (1930) (Chisala, 2019b, para 10). Section 137 creates the offense of "insulting the modesty of a woman" which provides that:

Whoever, intending to insult the modesty of any woman, utters any
word, makes any sound or gesture or exhibits any object intending
that such word or sound shall be heard, or that such gesture or object
shall be seen, by such woman or intrudes upon the privacy of such
woman, shall be guilty of a misdemeanour and shall be liable to
imprisonment for one year. (Malawi Penal Code, 1930,
section 137 (3))

While the language of the provision is clearly archaic, rooted in the patriarchal concept of female "modesty" (Chisala, 2019a), it is conceivable that IBSA could be prosecuted under this provision; intimate images being an "object" which "intrude upon the privacy" of a woman. In a recent IBSA case, a group of men were charged with insulting the modesty of a woman, among other offenses (Chisala, 2019a, para 10). This charge was made in response to an attack on a 
young woman, referred to here as "VK." ${ }^{4}$ In 2019, VK was attacked while wearing clothing supporting a political party. Supporters of an opposing party filmed her while forcibly removing her clothes. This video was shared widely. The incident triggered national uproar and demonstrations, which ultimately led to the perpetrators being charged with insulting the modesty of a woman, robbery, and use of force (Chisala, 2019a).

However, the offense of insulting the modesty of a woman cannot consistently provide appropriate redress for victims of IBSA. In practice, this provision has also been weaponized against human rights defenders, particularly the women it purports to protect. A recent, concerning, example of this involves Beatrice Mateyo, the Executive Director of the Coalition for the Empowerment of Women and Girls (Chisala, 2019a). Mateyo was arrested in 2017 for involvement in a feminist protest. During the protest, she carried a placard which stated "kubadwa ndi nyini si tchimo, my pussy my pride" (loosely translated into English to mean "to be born with a vagina is not a crime/sin, my pussy my pride"). Mateyo herself was arrested and charged with insulting the modesty of a woman. ${ }^{5}$ The Mateyo example is significant in that it demonstrates the dangers of imprecise criminal legislation. As the Penal Code currently stands, it is not unimaginable that a victim of IBSA may themselves be prosecuted under this provision (Chisala, 2019b, para 12).

The Mateyo example also illustrates wider, societal issues which are at play in Malawi in relation to IBSA. While the incident involving VK was widely condemned, including by the President and the media (Khamula, 2019), the response to Mateyo's case was more divided (Chisala, 2019a, para 11; Simango, 2017, para 4). In Malawi, there remains a desire to regulate female sexuality and to shame women themselves for perceived immodest behavior (Chisala, 2019a; ChisalaTempelhoff \& Kirya, 2016, pp. 3-4). Understanding this wider societal view is crucial to understanding the apparent failures of the existing criminal law in providing redress to victims of IBSA.

Nevertheless, as noted above, in recent years, more progressive legislation has been introduced which may be more appropriate in terms of protecting victims of IBSA. In particular, the Gender Equality Act 2013 presents some opportunity to protect victims of IBSA (Chisala, 2019b, paras 4-6; Chisala-Tempelhoff \& Kirya, 2016, p. 5). Section 5 of the Act states that "a person shall not commit, engage in, subject another person to, or encourage the commission of any harmful practice" (Gender Equality Act, 2013). Section 3 of the Act defines a harmful practice as a:

...social, cultural or religious practice which, on account of sex, gender or marital status does or is likely to (a) undermine the dignity, health or liberty of any person; or (b) result in physical, sexual, emotional, or psychological harm to any person. (Gender Equality Act, 2013)

Further, section 6 of the Act provides that: 
...a person commits an act of sexual harassment if he or she engages in any form of unwanted verbal, non-verbal or physical conduct of a sexual nature in circumstances in which a reasonable person, having regard to all the circumstances, would have anticipated that the other person would be offended, humiliated or intimidated. (Gender Equality Act, 2013)

An offense under these sections is punishable by a fine of one million Kwacha (approximately $£ 1,050 \mathrm{GBP}$ ) and a term of imprisonment of five years. While IBSA was not at the forefront of the drafters' minds in writing these provisions, it is conceivable that they could be expansively interpreted to prosecute IBSA (Chisala-Tempelhoff \& Kirya, 2016, p. 5). The focus on the harm caused to the individual is particularly pertinent in terms of McGlynn and Rackley's (2016, Image-based sexual abuse section, para 1) aforementioned definition of IBSA.

However, to date there have been no IBSA prosecutions under the Gender Equality Act 2013. Indeed, it is unclear if there have been any sexual harassment prosecutions whatsoever under the Act. The first high-profile prosecution was the case of Eric Aniva, who was prosecuted under the harmful practices provisions of section 5 for his role in conducting "sexual cleansing rituals" of women and girls in Nsanje (BBC News, 2016, para 10). However, this case provides very little by way of instruction on the possibility of using the legislation to protect victims of IBSA, particularly as it was decided in the Magistrates' Court and, as such, has no binding legal effect on other courts. It is, therefore, unclear how the law will be interpreted in the future. Furthermore, as with the offense of insulting the modesty of a woman, there is concern that if the provision was used to respond to an incident of IBSA, the victim could be prosecuted for engaging in the creation of their own intimate images.

The most pertinent piece of Malawian legislation in terms of prosecuting IBSA is the Electronic Transactions and Cyber Security Act 2016 (the 2016 Act) (Chisala, 2019b, para 8). The 2016 Act is a broad piece of legislation which attempts to regulate cyber-crime and data protection. However, in section 3(b), one of the stated objectives of the Act is also "to ensure that information and communication technology users are protected from undesirable impacts of information and communication technology, including the spread of pornographic material, cyber-crime and digital fraud" (2016 Act).

The 2016 Act is evidently not a specific piece of IBSA legislation. Aside from a provision concerning child pornography, the Act does not explicitly refer to IBSA. Nonetheless, it does prohibit cyber harassment, cyber stalking, and offensive communication under which IBSA can potentially be prosecuted. For example, section 87 prohibits "offensive communication," stating that "any person who willfully and repeatedly uses electronic communication to disturb or attempt to disturb the peace, quietness or right of privacy of any person" commits a misdemeanor (2016 Act). As noted by McGlynn and Rackley (2016, Imagebased sexual abuse section, p. 1), IBSA clearly "disturbs" the right of privacy of the victim (see, e.g., Bailey \& Mathen, 2019, p. 677; Dickson, 2016, p. 56). However, the requirement for repeated behavior is problematic. Furthermore, the 
provision is troubling because although it potentially lends itself to criminalizing IBSA, it could also be used to criminalize speech critical of the Government (Freedom House, 2019, section C2, para 2).

Section 86 of the 2016 Act prohibits cyber harassment, which focuses on anyone who uses a computer system and:

...continues (a) making any request, suggestion or proposal which is obscene, lewd, lascivious or indecent; or (b) threatening to inflict injury or physical harm to the person or property of any person; or (c) knowingly permits any electronic communications device to be used for any of the above-mentioned purposes. (2016 Act)

As with section 87, this provision could potentially be used to tackle IBSA, particularly in relation to those threatening to release intimate images, although the requirement for "continuing" behavior is once again unhelpful (2016 Act). Equally, the use of the language of obscenity and the focus on requests, suggestions, or proposals which are "obscene, lewd, lascivious or indecent" is problematic (2016 Act, s. 86). This language focuses once more on archaic notions of modesty that, like other provisions discussed above, could expose IBSA victims to prosecution.

Section 88 of the 2016 Act prohibits cyber stalking, which could also be invoked to prosecute IBSA. Under this provision, any person who "willfully, maliciously and repeatedly uses electronic communication to harass another person and makes a threat with the intent to instill reasonable fear in that person for his or her safety" commits an offense known as cyber stalking (2016 Act, s. 88). Section 88 would be useful in circumstances where repeated threats have been issued to disclose intimate images. In the Scottish context, it has been noted that threats can be a form of control in IBSA offenses (Brindley, 2015, para 3). However, the provision's efficacy is limited by the repeated behavior requirement. Furthermore, the provision could be open for abusive prosecution of vulnerable persons. For example, in 2020, a woman was prosecuted under section 88 for allegedly spreading "fake news" because she had posted a message to a WhatsApp group stating the FDH Bank was collecting information on citizens and passing this information to the Government (Nyasa Times, 2020, para 1). She was ultimately convicted of cyberstalking and given an 18 month suspended sentence and a fine of MWK 500,000 (Nyasa Times, 2020). This prosecution is concerning for a variety of reasons, not least in relation to freedom of speech. In terms of IBSA, this case demonstrates the potential use of the legislation to protect the powerful, rather than victims of misogynistic abuse.

Perhaps the most significant innovation of the 2016 Act is the takedown notification system. Section 30 details the responsibilities of intermediary service providers to takedown content that is unlawful or violates rights. Similarly, under section 96, anyone who is affected by a criminal offense may lodge a complaint with the Malawi Communications Regulatory Authority (MACRA) which then has the power to undertake investigations. 
In theory, the creation of these offenses should mean that MACRA and the police are able to tackle IBSA. Unfortunately, however, the authors are not aware of any IBSA investigations to date under this legislation. Indeed, recent reports involving the online abuse of women, which could have been prosecuted under the Act, appear not to have been fully investigated.

In 2018, over 200 women had their phone numbers leaked into a WhatsApp group by a Malawian man, where they were labeled "the easiest young women/ girls to sleep with or to have a good time" (Phiri, 2020, Public shaming and harassment on and offline section, para 1). These women received messages sexually harassing them, including pictures of male genitalia. While not an IBSA specific offense, this case was an opportunity to test the ability of the 2016 Act to protect women in online spaces. The victims reported the incident to the police. However, one of the victims noted that the police declined to investigate, stating that:

... this was a violation against a group of people; therefore, it needed several victims to come forward and accuse the young man for the case to be registered. Once the police turned me down and demanded a group report or no justice, most young women dropped off. (Phiri, 2020, Attempted collective response section, para 3)

It is concerning to hear this victim's account, which suggests the police shifted the focus to the victims themselves, requiring them to present evidence. This is particularly disappointing given the extensive evidence available in the public domain in this instance.

Women who are victims of IBSA offenses are often subjected to intense societal shaming (Chisala-Tempelhoff \& Kirya, 2016, pp. 3-7) and are ill-equipped to press for prosecution. A complaint in the aforementioned WhatsApp case was also lodged by the Young Feminists Network with the Malawi Human Rights Commission, although there has been no response to date (Chisala-Tempelhoff, 2020, Reporting remains a challenge section, para 2). It is unsurprising that the victim concluded from this experience that " $[\mathrm{t}] \mathrm{he}$ police make it difficult for victims of online violence to report" (Phiri, 2020, Attempted collective response section, para 6). Examples such as this may indicate a wider problem with police responsiveness to digital offenses against women in Malawi. Prosecutorial guidelines and extensive training are required if we are to ensure that cyber-laws are enforced to protect women in online spaces generally, as well as used to tackle IBSA specifically.

From this brief overview, it can reasonably be concluded that IBSA is not currently being addressed through the existing Malawian criminal law. Older, archaic pieces of legislation can be weaponized against women and other human rights defenders. Equally, more modern pieces of legislation which have the potential to protect victims of IBSA are not used to that effect. It is therefore tempting to suggest that specific IBSA legislation, such as that recently introduced in Scotland, may help address this issue. To assess the viability of this proposition, the benefits of the Scottish legislation are explored below. However, throughout 
this analysis, it is vital to recognize the wider social issues at play, including societal shaming concerning female sexuality and potential reluctance from the authorities to investigate online offenses. As will be explored in the Scottish context, these challenges cannot be solved through legislation alone.

\section{Scotland: Success and Shortcomings}

In Scotland, section 2 of the Abusive Behavior and Sexual Harm (Scotland) Act 2016 (the 2016 Act) creates the offense of disclosing, or threatening to disclose, an intimate photograph or film. Before the Act came into force, Scotland's legislative landscape resembled Malawi's in that a variety of different offenses were potentially applicable to IBSA. ${ }^{6}$ While these offenses continue to be available, the 2016 Act specifically focuses on the offense of disclosure of intimate images.

In the Policy Memorandum which accompanied the Bill it was noted that

...in the absence of an offense specifically concerned with the sharing of intimate images the exact scope of the law in this area can be seen by many as being unclear. (Scottish Parliament, 2015, para 26)

It was also noted that victims may not be aware that they were, in fact, victims of a criminal offense and that, even in those cases which did result in successful prosecutions, victims may not feel that their particular experiences were reflected in a prosecution based on the existing criminal law (Scottish Parliament, 2015, para 26). Equally, there were concerns that the legislative position before the 2016 Act made it difficult to strategically analyze and address the wider patterns of IBSA in Scotland, with it being suggested that "a piecemeal approach involving prosecutions under different statutes does not even allow for accurate collation of statistics to track the rise in the number of offenses" (Mawdsley, 2014, p. 5). Accordingly, creation of a discrete criminal offense was considered necessary.

This thinking did not take place in a Parliamentary vacuum. ${ }^{7}$ Indeed, Rackley (2019) has noted that the 2016 Act was a "legal landmark" in terms of women's rights, with campaigning by women's rights organizations being crucial in the process. In 2013, Scottish Women's Aid launched their campaign to end "revenge porn" which included the creation of dedicated websites. ${ }^{8}$ The websites provided a safe space for women who had been victims of IBSA to share their experiences and a space for others to display their support. The sites also offered advice to victims. The wider Scottish Women's Aid campaign involved training for civil servants and roundtables with legal experts (Hutchinson, 2013b, para 2) as well as a Parliamentary debate which received cross-party support (Scottish Parliament, 2013). As part of an extensive media campaign, Ellie Hutchinson of Scottish Women's Aid directly tackled the victim-shaming which often dominated public discourse at the time, noting that: 
One of the most consistent questions that women are asked is "why did you send/take those pictures?" To me, this is just a variation on the "why does she stay" theme, with added shaming around female sexuality. It places all the responsibility on the victim rather than the perpetrator... The question we really need to be asking (and answering) is not "why did you do it?", but "why does he think it's ok?" (Hutchinson, 2013a, paras 5-6)

The campaign also acknowledged that the young people who tended to be the victims of these offenses experienced "a particular kind of disbelief and minimizing" (Hutchinson, 2013b, para 5) with those in authority failing to acknowledge the significance of online crimes. This reframing of the narrative around IBSA, focusing on the need for education, and prevention and to encourage women to come forward, was significant in tackling IBSA in Scotland.

Following commencement of the campaign, discussions began to take place as to whether the existing law was adequate (see, e.g., Rose, 2013; Whitelaw, 2014). In March 2015, the Government launched a consultation seeking views on the creation of a new criminal offense (Scottish Government, 2015). It is important to note that, while the manner in which the consultation process was conducted was not without its critics (Chalmers, 2015, p. 400) a resounding majority $(99 \%)$ of those who responded agreed that a specific offense should be created (Scottish Parliament, 2015, para 38). This consensus that disclosure of intimate images was a discrete criminal offense requiring clear regulation was in many ways remarkable given that the public awareness campaign was launched only two years previously. With regards to raising awareness of IBSA and emphasizing the criminality of this behavior, this campaigning appears to have been successful. As mentioned above, Rackley (2019, p. 643) has praised the work of Scottish Women's Aid in particular, noting that the 2016 Act is "a clear example of the power of sustained and collective feminist campaigning." The central role that this campaigning played in Scotland should be kept in mind when drawing comparisons between the Scottish and Malawian contexts, given that no similar IBSA campaign has as yet emerged in Malawi. Section 2 of the Act entered into force on July 3, 2017 alongside a media campaign entitled "Not Yours to Share."

Section 2 of the 2016 Act has three core requirements to prove an offense. Firstly, a person ("person A") discloses or threatens to disclose, a photograph or film which shows, or appears to show, another person ("person B") in an intimate situation (2016 Act). Secondly, A must intend to cause B fear, alarm, or distress, or be reckless as to whether this is the case (2016 Act). Finally, the photograph or film must not have previously been disclosed to the public by B or with B's consent (2016 Act). In this context, disclosure occurs if a photograph or film, "or any data or other thing which is capable of being converted into it" is given, shown or made available to someone other than person B (2016 Act, s. 2).

Section 3 defines an "intimate situation" as being one where the person is engaging or participating in, or present during, an act which a reasonable person would consider to be a sexual act and which is not of a kind ordinarily done in public; or if the person's genitals, buttocks, or breasts are exposed or covered only 
with underwear (2016 Act). Available defenses under section 2(3) include that person $\mathrm{B}$ consented to the disclosure or that person A reasonably believed that $\mathrm{B}$ consented to the disclosure (2016 Act). The maximum penalty on summary conviction is 12 months in prison or a fine not exceeding the statutory maximum (or both) or, on conviction on indictment, to five years in prison or a fine (or both) (2016 Act, s. 2(7)).

There are a number of positive aspects of the offense. For example, mens rea is constituted through either intention or recklessness. This may be contrasted, for example, with the equivalent legislation in England and Wales. Section 33 of the Criminal Justice and Courts Act 2015 does not criminalize reckless behavior. The inclusion of recklessness recognizes the wide range of circumstances in which disclosure may occur. A perpetrator may, of course, intend to cause their victim fear, alarm, or distress, as is seen in paradigmatic "revenge porn" cases. However, it is also important to recognize the wider nature of the offense and understand that there will be cases where this intention is not present and the perpetrator is reckless as to whether they cause fear, alarm, or distress. It is important that victims in these circumstances are also protected.

Another positive element of the Scottish framework is the offense's application both to actual disclosure and to the threat of such disclosure. The inclusion of threats is important in recognizing that IBSA can form part of a wider pattern of domestic abuse. Sharing their experience in evidence to Parliament on the Bill, Rape Crisis Scotland explained that

[t]hreats to share images of this nature are often used following the ending of a relationship, or as a way of coercing someone to do something they do not wish to do. (Brindley, 2015, para 3)

The equivalent legislation in England and Wales does not include threats and instead requires actual disclosure. Pegg (2018) has noted "there are potential difficulties with this omission," (p. 517) explaining:

In October 2017 Daniel Stainton was convicted of blackmail and disclosing private sexual images after he threatened three women with the disclosure of the intimate images the women had shared with him. The money Stainton extorted from one of his victims ensured the offense of blackmail could be made out, but to rely on blackmail to police this behaviour is to assume that perpetrators will be looking to make a gain in money or other property. (Pegg, 2018, p. 517)

It is therefore clear that the inclusion of threats to disclose was crucial in terms of ensuring that the full extent of IBSA was capable of prosecution in Scotland.

Furthermore, it is important that the section 3(2) of the Act specifically provides that films or photographs that have been altered in any way are included within the scope of the offense. In doing so, the Act ensures that a wide range of IBSA is captured. As noted by McGlynn and Rackley (2015, para 5.3) in their 
evidence provided to the Scottish Parliament's Justice Committee, "[t]he harm to a victim's dignity, and the harm which comes from images going viral, is the same whether or not the image is an 'original' or altered."

In many ways, therefore, the legislation itself can be said to be exemplary, wide-ranging yet nuanced in its drafting. However, to understand the impact of the legislation it is, of course, essential to understand how it is operating in practice. The first successful prosecution came shortly after section 2 came into force. The Crown Office \& Procurator Fiscal Service released a statement emphasizing that "victims are in no way responsible just because they may have consented to an image being taken" (Crown Office \& Procurator Fiscal Service, 2017, para 10). It was hoped that this early prosecution would reassure victims that the criminal justice system could provide adequate redress.

The recent case of Shanks v Procurator Fiscal, Glasgow [2018] SAC (Crim) 18 confirms the severity with which this behavior is to be treated. Shanks had threatened to disclose intimate images of the complainer to her children. The Sheriff Appeal Court noted that, considering the maximum sentencing available under the Act, it is "clear that Parliament views these offenses extremely seriously" and that

...an individual who has entrusted a partner with an intimate image is entitled to a reasonable expectation that the court will deal severely with those who perpetrate this type of offense. (Shanks v Procurator Fiscal, Glasgow [2018] SAC (Crim) 18 para 3)

This case emphasizes the abusive nature of this offense and demonstrates that the judicial system will treat seriously threats to disclose, even without actual disclosure.

However, it is important to acknowledge the limitations of the Scottish legislation. Statistics provide a crucial insight into the effectiveness of the new regime. Section 2 came into force in July 2017, and 421 new crimes of disclosing or threatening to disclose an intimate image were recorded in the period July 3, 2017 to March 2018 (Scottish Government, 2019, p. 36). In 2018-2019, the first full reporting year in which section 2 was in force, 596 crimes were recorded (Scottish Government, 2019, p. 36). To fully understand these statistics, it is necessary to delve beyond the recording rate.

In March 2018, BBC Scotland published data they had obtained through a series of freedom of information requests made to Police Scotland (Ellison, 2018). Between July and December 2017, 225 complaints were reported to the Police but only 89 were detected (Ellison, 2018, para 2). The BBC explains that detected in this context means "that an accused has been identified, and that a report may be referred to the Crown Office or the Scottish Children's Reporter for consideration" (Ellison, 2018, Women victims section, para 3). The low proportion of detected cases raised concerns. Glasgow Women's Aid stated they were "disappointed" by these statistics, particularly given that "it must be extremely difficult to come forward and extremely demoralising if the complaint does not progress" (Ellison, 2018, How was "revenge porn" distributed section, para 4). In response, Police Scotland stated that these investigations were often "very complex" and 
that they would "encourage victims to come forward early which will better enable us to get evidence from any devices, or provide support to them, and advise how best to minimise impact" while also noting that there may also be an issue of under-reporting due to the shame surrounding the offense (Ellison, 2018, Police won't judge you section, para 3).

More recent data suggests that detection remains an issue..$^{10}$ In 2018-2019, 596 crimes were recorded but only 44.5\% were detected (Police Scotland, 2019, p. 5). The data for 1 April to December 31, 2019 shows 478 crimes had been recorded by the end of the third quarter, and that the detection rate is $46.7 \%$ (Police Scotland, 2020, p. 5). To compare these figures to other sexual crimes, the detection rate for rape is $51.6 \%$ and for taking, distributing, and possessing indecent photos of children is $94.9 \%$ (Police Scotland, 2020, p. 5). The detection rate for intimate image sharing is the lowest rate for all sexual crimes (Police Scotland, 2020, p. 5). This suggests that there are clear challenges in police detection for these offenses and, ultimately, prosecution. Accordingly, it would seem that even IBSA specific legislation leaves much to be desired in terms of providing redress.

\section{Conclusion: Inherent Limitations of Criminal Law and Need for a Multi-Pronged Approach}

Having examined the criminal legislative landscapes in both countries, it is clear that neither legal system is responding perfectly to IBSA. While the problems in each nation are rooted in distinct local contexts, there are core commonalities in terms of the challenges presented in successfully policing and prosecuting IBSA.

Scotland's 2016 Act is, in many ways, an excellent example of criminal legislation responding to IBSA. In particular, the comprehensive drafting, which allows for the inclusion of a broad spectrum of IBSA (including the threat to disclose intimate images), is to be commended. In being an IBSA specific provision, the legislation avoids some of the unintended consequences inherent in the existing Malawian legislation, where archaic and imprecise offenses can be used to turn victims into accused (Chisala, 2019b, para 12). Equally, section 2 of Scotland's 2016 Act clearly articulates that IBSA is a criminal offense, alleviating any confusion on this point.

This raises the question as to whether a further, IBSA specific offense may be beneficial in Malawi. In our view, the answer to this question, at this time, is "no." The current Malawian criminal law clearly has limitations and is undeniably imperfect. However, there is some potential to use existing legislation to tackle IBSA through "nuanced" interpretation (Chisala-Tempelhoff \& Kirya, 2016, p. 8). ${ }^{11}$ Specific IBSA legislation may ultimately prove helpful in Malawi but it is crucial to remember that Scotland's 2016 Act was born of a lengthy public education and media campaign by feminist activists (Rackley, 2019, p. 643) and was introduced with overwhelming support for a specific IBSA offense. It is vital to engage with this wider context in order to understand what can be learned from the Scottish experience. Even against this backdrop of campaigning and 
consensus, detection rates in Scotland remain worryingly low. In the local Malawian context, introducing further legislation at this time risks futility.

To understand why this is the case, it is helpful to recall our earlier reference to the Constitution of Malawi and the rights protected therein. While these rights are protected by the Constitution, the reality of being able to enforce these rights is, in practice, challenging. Copies of the Constitution are not widely available to the public. They are also often not available to the police and other justice actors including magistrates. There are some versions of the Constitution and key gender-related laws which have been translated into local languages other than English, but these are neither widely available nor easily accessible. Lack of public accessibility is typical of significant swathes of Malawian legislation. Efforts to digitize Malawian legal resources are ongoing. For example, the Gender and Justice Unit ${ }^{12}$ hosts MalawiLII.org, part of a broader effort to ensure online availability of Malawian legislation and case law. However, public engagement with the law remains low. Furthermore, the digital divide in Malawi is significant in this context. It is estimated that in 2017 , only $13.78 \%$ of the population had internet access (International Telecommunications Union, 2019). This restricts the ability of the public to engage with new offenses as they are created. Even where complete versions of legislation are readily available, they tend to be in a format that is difficult for the wider population to consume. Data from 2015 demonstrate that Malawi has low literacy rates and these rates are significantly lower when disaggregated by gender (UNESCO, 2019a; 2019b). Women lag far behind. Work is ongoing to counter these issues. ${ }^{13}$ Nevertheless, it is important to acknowledge that much remains to be done in terms of ensuring access to justice for women and girls. While these issues of accessibility are, of course, wider than IBSA offenses, they illustrate the challenges associated with creating an effective criminal offense in this context.

Equally, it is important to recognize the wider social context in which these crimes are occurring in Malawi. Social condemnation of the victims of IBSA is widespread, as "the public largely scorns and shames the female victims, women whose lives are already irreparably changed" (Chisala-Tempelhoff \& Kirya, 2016, p. 4). As demonstrated in the Mateyo example discussed above, there remains a strong social stigma surrounding female sexuality, and a culture of shame is pervasive. As noted by Chisala-Tempelhoff and Kirya (2016, p. 3), "[w]omen who are perceived as deviating from this norm, for example, by 'allowing' themselves to be photographed naked, are derided and chastised in the court of public opinion." This is, of course, not unique to Malawi; victim shaming in IBSA cases is a global phenomenon which has also been recognized in the Scottish context (see, e.g., Hutchinson, 2013a). However, it is crucial to understand the prevalence of these attitudes in Malawi to understand how IBSA can effectively be challenged and prosecuted. Our previous discussion about the Electronic Transactions and Cyber Security Act and potential police and prosecutorial reluctance alludes to a wider societal minimization of online offenses such as IBSA.

It is also important to acknowledge the wider issues concerning reliance on the criminal law in this context (Chisala-Tempelhoff, 2020, Is the law enough section, para 4). The criminal law is often used against the vulnerable and therefore 
cannot be treated as a comprehensive solution for IBSA victims. Again, this analysis is not unique to the Scottish and Malawian criminal justice systems. In the Canadian context, Bailey and Mathen $(2019$, pp. 666, 668, 695) have noted that criminal law has a disproportionate impact on minority and marginalized groups. They also note that

...the kind of long-term social transformation that will be necessary to eradicate the sorts of GBV evident in cases of TFVAWG far exceeds the capacity of a reactive and punitive criminal law system. (Bailey \& Mathen, 2019, p. 695)

Over-reliance on the criminal law therefore can be harmful and we need to ensure that criminal law is only one thread in a wider tapestry of responses. As noted by Bailey and Mathen (2019, p. 695), "In many cases, survivors will have good reason to take a different approach." One such reason victims may pursue a "different approach" is the length of time it takes to receive a criminal justice response. As Dickson (2016, p. 51) has argued with reference to the Australian legal system, a swift response is essential in IBSA cases where removal of the images is particularly important in terms of protecting victims from ongoing abuse. As Dickson (2016, p. 52) notes

...the criminal law does not provide victims with an efficient and accessible means for obtaining the removal of revenge pornography from the internet. While criminal laws are important, they are not sufficient in isolation.

It is therefore vital that any responses to tackling IBSA in Malawi and in Scotland do not rely solely on the criminal justice system.

For these reasons, we expect that Malawi's existing criminal legislation will continue to yield unsatisfactory results and further legislation risks becoming yet another a paper tiger without wider civic campaigning. Therefore, we would suggest that the focus in Malawi, at this time, ought to be on campaigning, community engagement, and training of front-line services to raise awareness of IBSA. Such an approach would be in keeping with Rackley's (2019) observations about the vital role that the Women's Aid campaigning played in Scotland before the introduction of IBSA legislation.

To return to the present Scottish landscape, it is equally clear that public legal education and training of front-line services have a continuing role to play if we are to see effective use of the new criminal law. In the words of the First Minister in 2018 , when asked about the lack of prosecution

...while putting laws in place is important, making sure that these laws can effectively be used is what matters most and I think these statistics tell us that there is still work to be done on this important issue. (The Scotsman, 2018, para 10) 
In terms of the "work" now to be done, we need to focus on how to ensure IBSA offenses are prosecuted under Scotland's 2016 Act. Police Scotland has stated that investigations are "very complex" (Ellison, 2018, Police won't judge you section, para 1). A helpful starting point could potentially be reviewing the particular difficulties officers encounter with a view to increasing detection rates. Similarly, while public legal education to date has been significant, maintaining this momentum and distributing high-quality resources throughout Scotland is likely to be essential to encouraging reporting and continued de-stigmatization of IBSA.

Ultimately, we owe the victims of IBSA, in Scotland and in Malawi, a nuanced response which invokes the power of the criminal law while also recognizing the need for wider civil society engagement. Tackling IBSA in both Scotland and Malawi will require a societal shift driven by continual, strategic campaigning, and collaboration across sectors. As lawyers, we must therefore engage with the importance of public legal education and cross-sector partnerships to deliver justice in the fullest sense.

\section{Notes}

1. The authors would like to thank Eleanor Livingston LLB (Hons) for her insightful research and work on earlier drafts. Her support has been invaluable, and we are greatly indebted to her. The authors would also like to thank Wangari Mwenda LLB for research support in the Malawian context and both Chikondi Mandala (Legal Research Associate, Gender and Justice Unit Malawi) and Maria Fletcher (Senior Lecturer, University of Glasgow) for their comments and support. Any errors are those of the authors.

2. Specifically, in relation to IBSA, jurisdictions including England and Wales; Germany; and States across the US have created offenses. See, Scottish Government (2015, pp. 16-17) for a brief discussion of these jurisdictions.

3. In this chapter, the authors focus on legislation which creates IBSA offenses. It should be noted that there are other Malawian laws which may be relevant in this context which are not discussed, including obscenity provisions in the Malawi Penal Code (1930) and the Prevention of Domestic Violence Act 2006. For further information and discussion of these pieces of legislation, please refer to Chisala-Tempelhoff and Kirya (2016) and Chisala (2019b). Similarly, the authors acknowledge that civil law mechanisms are available in our respective domestic jurisdictions although an analysis of these remedies is outside the scope of this discussion.

4. While the victim in this incident has been named widely in Malawian media, we have chosen to refer to her only by her initials.

5. The case is ongoing. Mateyo is represented by the Women Lawyers Association of Malawi, who have submitted that the offense is inappropriately broad and, supported by the Southern Africa Litigation Center, are seeking to challenge the law through a public interest litigation (Chisala, 2019a).

6. For a non-exhaustive list of relevant available offenses before the 2016 Act, see, Scottish Parliament (2015, para 25). 
7. Discussions around specific IBSA offenses were taking place across the jurisdictions of the United Kingdom at this time. Scotland has a distinct legal system from England and Wales, but it is important to note that England and Wales introduced an IBSA offense in 2015 through the Criminal Justice and Courts Act 2015. For a discussion of the parallel journeys toward the creation of IBSA offenses in both Scotland and England and Wales, see, Rackley (2019).

8. Scottish Women's Aid created the site "Stop Revenge Porn Scotland" (available at https://stoprevengepornscotland.wordpress.com/) to share information in relation to revenge porn and highlight the ways in which they could support victims. Separately, a Flickr site was also created (available at https://www.flickr.com/photos/scottishwomensaid/sets/72157634479421774/) to allow individuals to share messages of support.

9. "Not Yours to Share" is a Scottish Government campaign which was created in partnership with Police Scotland, the Crown Office, and a variety of third sector organizations. The website (available at http://notyourstoshare.scot/) assisted individuals in understanding how the new law would operate.

10. It is important to understand that the statistics referred to here are from Police Management Information Quarterly Reports. The data used in these reports are provisional and do not constitute official statistics. The reports make clear that the official statistics produced by the Scottish Government should be relied on when drawing longer term trend comparisons. However, given that the 2018-2019 National Statistics do not offer information on detections and the 2019-2020 official statistics are not yet available, we refer here to the Police Management Information Statistics, while noting the caveats contained therein.

11. Chisala-Tempelhoff and Kirya (2016, p. 8) have previously advocated for "specific legislation or a nuanced interpretation of existing laws" in the Malawian context. While it is submitted herein that further legislation may risk futility in the present climate, and a nuanced interpretation of the existing law is therefore preferable, it is acknowledged that specific legislation may be beneficial in the future.

12. An organization which was founded by one of the authors.

13. For example, the Malawian Gender and Justice Unit has researched women's ability to access civil justice and developed simplified versions of critical legislative provisions accompanied by detailed process charts to bridge the gap between women and the justice solutions promised by legislation (see, Gender and Justice Unit, 2019).

\section{References and Resources}

Bailey, J. \& Mathen, C. (2019). Technology-facilitated violence against women \& girls assessing the Canadian criminal law response. The Canadian Bar Review, 97(3), 664-696. Retrieved from https://cbr.cba.org/index.php/cbr/article/view/4562

BBC News. (2016, November 22). Malawi 'hyena man' Eric Aniva sentenced to two years hard labour. BBC News. Retrieved from https://www.bbc.co.uk/news/worldafrica-38063345

BBC News. (2017, July, 3). New 'revenge porn' law comes into force in Scotland. BBC News. Retrieved from https://www.bbc.co.uk/news/uk-scotland-40473912 
BBC News. (2020, January 6). Number seeking advice over revenge porn doubles. BBC News. Retrieved from https://www.bbc.co.uk/news/uk-scotland-50998325

Brindley, S. (2015). Written submission from Rape Crisis Scotland to the Scottish Parliament Justice Committee on the Abusive Behaviour and Sexual Harm (Scotland) Bill. Retrieved from http://www.parliament.scot/S4_JusticeCommittee/ Inquiries/ABSH9._Rape_Crisis_Scotland.pdf

Brown, J. (2018). 'Revenge porn' and the actio iniuriarum: Using 'old law' to solve 'new problems'. Legal Studies, 38, 396-410. doi:10.1017/1st.2018.8

Brown, G. (2019). Voyeurism by "observing" and "recording" the complainer - the decision in KT v PF. Falkirk Green's Criminal Law Bulletin, 157, 5-7.

Chalmers, J. (2015). Criminal law reform in Scotland. Edinburgh Law Review, 19(3), 399-403. doi:10.3366/elr.2015.0302

Chisala, S. (2019a, May 9). Insulting the Modesty of a Woman" and the push by the women's movement in Malawi. [Web log post]. Retrieved from https://africanfe minism.com/insulting-the-modesty-of-a-woman-and-the-push-by-the-womensmovement-in-malawi/

Chisala, S. (2019b, 15 August). Malawi: Criminal law responses to non-consensual distribution of intimate images. [Web log post]. Retrieved from https:// www.uofgschooloflaw.com/blog/2019/8/14/malawi-criminal-law-responses-to-nonconsensual-distribution-of-intimate-images

Chisala-Tempelhoff, S. (2020, June 4). Accessing justice for image-based sexual abuse: A challenge for victims in Malawi. [Web log post]. Retrieved from https:// africanfeminism.com/accessing-justice-for-image-based-sexual-abuse-a-challengefor-victims-in-malawi/

Chisala-Tempelhoff, S., \& Kirya, M. T. (2016). Gender, law and revenge porn in SubSaharan Africa: A review of Malawi and Uganda. Palgrave Communications, 2, 16069. doi:10.1057/palcomms.2016.69

Cowan, S. (2019). Sense and sensibilities: A feminist critique of legal interventions against sexual violence. Edinburgh Law Review, 23(1), 22-51. doi:10.2139/ ssrn. 3429595

Crofts, T., \& Kirchengast, T. (2019). A ladder approach to criminalizing revenge pornography. Journal of Criminal Law, 83(1), 87-103. doi:10.1177/00220183188 14361

Crown Office \& Procurator Fiscal Service. (2017, September 4). First 'intimate images' conviction under new legislation. [Web log post]. Retrieved from https:// www.copfs.gov.uk/media-site/media-releases/1594-first-intimate-images-convictionunder-new-legislation

Dickson, A. (2016). 'Revenge Porn': A Victim Focused Response. UniSA Student Law Review, 2, 42-69. doi:10.21913/USLRunisaslr.v2i0.1357

Ellison, M. (2018, March 6). Less than half revenge porn cases passed to prosecutors. BBC News. Retrieved from https://www.bbc.co.uk/news/uk-scotland-42689607

Freedom House. (2019). Freedom on the net 2019: Malawi. Retrieved from https:// freedomhouse.org/country/malawi/freedom-net/2019\#footnote4_6fnynzz

Gender and Justice Unit. (2019). The civil justice needs booklet. Retrieved from http:// www.genderandjustice.org/wp-content/uploads/2019/12/The-GJU-Civil-JusticeNeeds-Booklet-2019.pdf

Hutchinson, E. (2013a, August 5). Stop revenge porn. [Web log post] Retrieved from https://thefword.org.uk/2013/08/stop_revenge_porn/ 
Hutchinson, E. (2013b, October 5). We need to talk about revenge porn. New Statesman. Retrieved from https://www.newstatesman.com/politics/2013/10/weneed-talk-about-revenge-porn

International Telecommunication Union. (2019). Percentage of individuals using the internet. Retrieved from https://www.itu.int/en/ITU-D/Statistics/Documents/ statistics/2019/Individuals_Internet_2000-2018_Dec2019.xls

Kettles, L. (2015). Written submission from the Scottish Women's Convention to the Scottish Parliament Justice Committee on the Abusive Behaviour and Sexual Harm (Scotland) Bill. Retrieved from https://www.parliament.scot/S4_JusticeCommittee/ Inquiries/ABSH4._SWC.pdf

Khamula, O. (2019, January 24). Court refuses bail to UTM woman undressing suspects: Case adjourned to Feb 6. Court refuses bail to UTM woman undressing suspects: Case adjourned to Feb 6. Nyasa Times. Retrieved from https:// www.nyasatimes.com/court-refuses-bail-to-utm-woman-undressing-suspects-caseadjourned-to-feb-6/

Mawdsley, G. (2014, December). "Hell hath no fury like a person scorned": Considering the offence of "revenge porn". Green's Criminal Law Bulletin, 132, 2-4.

McGlynn, C., \& Rackley, E. (2015). Written submission from Professor Clare McGlynn (Durham University) and Professor Erika Rackley (University of Birmingham) to the Scottish Parliament Justice Committee on the Abusive Behaviour and Sexual Harm (Scotland) Bill. Retrieved from https://www.parliament.scot/ S4_JusticeCommittee/Inquiries/ABSH3._McGlynn_and_Rackley.pdf

McGlynn, C., \& Rackley, E. (2016, February 15). Not 'revenge porn', but abuse: let's call it image-based sexual abuse. [Web log post] Retrieved from https://inherentlyhuman. wordpress.com/2016/02/15/not-revenge-porn-but-abuse-lets-call-it-image-basedsexual-abuse/

McGlynn, C., \& Rackley, E. (2017). Image based sexual abuse. Oxford Journal of Legal Studies, 37(3), 534-561 doi:10.1093/oj1s/gqw033

McGlynn, C., Rackley, E., \& Houghton, R. (2017). Beyond 'revenge porn': The continuum of image-based sexual abuse, Feminist Legal Studies, 25, 25-46. doi: 10.1007/s10691-017-9343-2

McGlynn, C., \& Westmarland, N. (2019). Kaleidoscopic justice: Sexual violence and victim-survivors' Perceptions of justice. Social \& Legal Studies, 28(2), 179-201. doi: $10.1177 / 0964663918761200$

Nyasa Times. (2020, April 17). Blantyre woman convicted for spreading fake news against FDH Bank on Whats App. Nyasa Times. retrieved from https:// www.nyasatimes.com/blantyre-woman-convicted-for-spreading-fake-news-againstfdh-bank-on-whatsapp/

Pegg, S. (2018). A matter of privacy or abuse? Revenge porn in the law. Criminal Law Review, 7, 512-530.

Phiri, B. (2020, June 1). How leaking of my contact data triggered an avalanche of online abuse. [Web log post]. Retrieved from https://africanfeminism.com/howleaking-of-my-contact-data-triggered-an-avalanche-of-online-abuse/

Police Scotland. (2019). Management Information: Force Report: Quarter 4 2018/2019. Retrieved from https://www.scotland.police.uk/spa-media/ixxlpvxe/managementinfo-report-q4-2018-19.pdf 
Police Scotland. (2020). Management Information: Force report: Quarter 3 2019/ 2020. Retrieved from https://www.scotland.police.uk/spa-media/ffypnwyw/forcemi-q3.pdf

Rackley, E. (2019). Section 2 of the Abusive Behaviour and Sexual Harm (Scotland) Act 2016. In E. Rackley, \& R. Auchmuty (Eds.), Women's legal landmarks: Celebrating the history of women and law in the UK and Ireland (pp. 637-643). Oxford: Hart Publishing. doi:10.5040/9781782259800.ch-001

Rose, G. (2013, September 28). Crackdown promised over online revenge porn videos. The Scotsman. Retrieved from https://www.scotsman.com/news/politics/crackdown-promised-over-online-revenge-porn-videos-1559797

Scottish Government. (2015). Equally Safe - Reforming the criminal law to address domestic abuse and sexual offences consultation paper. Retrieved from https:// www2.gov.scot/Resource/0047/00473932.pdf

Scottish Government, National Statistics Publication for Scotland. (2019). Recorded Crime in Scotland 2018 - 2019. Retrieved from https:/www.gov.scot/publications/ recorded-crime-scotland-2018-19/

Scottish Parliament. (2013, September 11). End revenge porn debate. Retrieved from https://www.theyworkforyou.com/sp/?id=2013-09-11.22.0

Scottish Parliament. (2015). Policy Memorandum Abusive Behaviour and Sexual Harm (Scotland) Bill. Retrieved from https://www.parliament.scot/ S4_Bills/Abusive\%20Behaviour\%20and $\% 20$ Sexual $\% 20 H a r m \% 20($ Scotland) $\% 20$ Bill/ SPBill81PMS042015.pdf

Scottish Parliament Justice Committee. (2016). Stage 1 Report on the Abusive Behaviour and Sexual Harm (Scotland) Bill (SP paper 885.1 2nd report, 2016 (Session 4)). Retrieved from https://www.parliament.scot/S4_JusticeCommittee/ Reports/JS042016R02Rev.pdf

Simango, W. (2017, 14 September). Woman arrested for protesting against gender based violence. Malawi 24. Retrieved from https://malawi24.com/2017/09/14/ woman-arrested-protesting-gender-based-violence/

The Republic of Malawi and Scotland. (2018). Global Goals Partnership Agreement. Retrieved from https://www.gov.scot/publications/global-goals-partnership-agree ment-between-scotland-and-malawi/

The Scotsman. (2018, March 8). First Minister 'concerned' by revenge porn detection rate. The Scotsman. Retrieved from https://www.scotsman.com/news/politics/firstminister-concerned-revenge-porn-detection-rate-330278

The World Bank. (2015). Country at a Glance - Malawi. Retrieved from https:// datatopics.worldbank.org/education/country/malawi

The World Bank. (2018). Individuals using the Internet (\% of population). Retrieved from https://data.worldbank.org/indicator/IT.NET.USER.ZS?end=2018\&most_ recent_value_desc $=$ true $\&$ start $=1960$

UNESCO Institute for Statistics. (2019a). Adult Literacy rate, population, 15+ years, female (\%). Retrieved from http://data.uis.unesco.org/index.aspx?queryid $=121$

UNESCO Institute for Statistics. (2019b). Adult Literacy rate, population, 15+ years, male (\%). Retrieved from http://data.uis.unesco.org/index.aspx?queryid=121

Whitelaw, J. (2014, April 10). Call for internet revenge porn legislation. The Scotsman. Retrieved from https://www.scotsman.com/news/politics/call-internet-revengeporn-legislation-1540012 
532 Seonaid Stevenson-McCabe and Sarai Chisala-Tempelhoff

\section{Case law and legislation}

Abusive Behaviour and Sexual Harm (Scotland) Act 2016

Criminal Justice and Courts Act 2015

Electronic Transactions and Cyber Security Act 2016

Gender Equality Act 2013

Malawi Penal Code 1930 (consolidated 2014, December 31)

Prevention of Domestic Violence Act 2006

Shanks v Procurator Fiscal, Glasgow [2018] SAC (Crim) 18

The Constitution of the Republic of Malawi. (1994). 